\title{
Asthma in children and adults: A shared biological and molecular basis
}

\author{
PAOLO M RENZI MD \\ Pulmonary Unit, Notre Dame Hospital, University of Montreal, and Meakins Christie \\ Laboratories, McGill University, Montreal, Quebec
}

PM RenZI. Asthma in children and adults: A shared biological and molecular basis. Can Respir J 1995; 2(Suppl A):5A-9A.

The objective of this paper is to describe the important clinical, physiological, immunological and biological similarities among asthmatic infants, children and adults. A comparison of the reported clinical presentation, physiological changes, histology and cellutar biology of asthma in different age groups is presented with special emphasis on the abnormal immune response, cellular activation and lymphokine production. Different age groups of asthmatics have important similarities in clinical presentation, lung physiology and histopathology. Eosinophilia and increased immunoglobulin (Ig) E levels are present at every age except in young infants. Signs of cellular activation and increased production of lymphokines of the type 2 helper $T$ lymphocyte, which can increase $\lg E$ levels and affect eosinophils, are also found in every age group. These abnormalities have been shown in animal models to cause airway inflammation and physiological changes comparable with those encountered in asthma. In conclusion, future studies should try to identify the specific characteristics of the population at risk for asthmat, emphasizing not only primary prevention but also the use of inhibitors or modulators of the inflammatory reaction that is present in the airways of asthmatics.

Key Words: Asthma, Cyokines, Children, I.mphuerye suhsets

\section{L'asthme chez les enfants et les adultes : Une base moléculaire et biologique partagée}

RESUMË : Cet article a pour objectif de décrire les importantes similitudes bologiques, immunologiques, physiologiques et cliniques que l'on observe parmi les bambins, les enfants et les adultes asthniatiques. On présente une comparaison de la biologie cellulaire, de l'histologie, des changements physiologiques et des symptômes cliniques de l'asthme qui ont étci rapportés dans différents groupes. On insiste particulièrement sur l'anormalité de la réponse immunitaire, de la production de lymphokines et de l'activation cellulaire. Des asthmatiques appartenant à des classes d'âge différentes présentent des similitudes importantes dans les symptômes cliniques, la physiologie pulmonaire et l'histopathologie. L'éosinophilie et l'augmentation des taux d'immunoglobulines (Ig)E sont observées à tout âge sauf chez les nourrissons. On observe également dans chaque classe d'âge des signes d'activation cellulaire et d'une production accrue de lymphokines de lat classe des lymphocytes $T$ auxiliaires de type 2, qui peuvent accrô̂tre les taux d’IgE et avoir une incidence sur les éosinophiles. L'expérimentation animale a démontré que ces anormalités étaient responsables de l'inflammation des voics aériennes et des changements physiologiques, et qu'elles étaient comparables à celles observées dans l'asthme. En conclusion, les chercheurs devront essayer d'identifier les caractéristiques spécifiques de la population à risque pour l'asthme et mettre l'accent non seulement sur kic rôle de lis prévention primaire mais également sur l'utilisation d inhibiteurs ou de modulateurs de la reation inflammatoire présente dans les voies aériemnes des asthmatiques. 
A STHMA IS A DISEASI: OI: THE LUNG'S AIRWAYS THAT HAS a complex pathotenesis. Unsuccessful attcmpts at defining asthma may be related to a certain degree of heterogeneity in the triggers of this disease and the increasingly sought for, yet fleeting, 'cause' of asthma. Nevertheless, asthma can be characterized by two important physiological observations: reversible airway obstruction and increased airway responsiveness to specific and nonspecific stimuli (1). The reversibility of airway obstruction in asthma can be ascertained by recognizing an important kmporal variation in the symptoms of shortness of breath, cough and wheezing. A clinical impression can then be confirmed by showing a variability in sequential measurements of peak expiratory flow rates or spirometric improvement in airway obstruction after a bronchodilator. The increase in symptoms when patients are exposed to triggers such as cold air, exercise, irritants, allergens and viral infections are signs of airway hyperresponsiveness that can be confirmed in the laboratory by measuring increased airway responsiveness to histamine and methacholine or even by the assessment of an increased airway obstructive response to an antigen (2).

An increase in the number of hospitalizations due to asthma mostly in the age group of zero to four years and the increased mortality in young asthmatic patients during the 1980 s $(3,4)$ has led to a broader interest into the pathophysiology of asthma.

\section{ASTHMA AND INFLAMMATION}

A detailed analysis of the clinical, biological and histological characteristics of asthma has led to the conciusion that asthma is an inflammatory disease of the airways and that the inflammation that is present in the airways of asthmatics could lead to chronic and possibly irreversible changes affecting the physiological responses to different stimuli $(5-7)$.

Histopathology shows typical changes. The submucosil is infiltrated with eosinophils. lymphocytes, mast cells and macrophages and the blood vessels are dilated (5-7). The epithelium is particularly damaged, vacuolated, infiltrated by inflammatory cells and cilia are often absent. In places the epithelium is sloughed off laving a bare basement membrane thickened by collagen deposition. There is also an increase in mucosal goblet cells, bronchial mucus glands and hypertrophy or hyperplasia of smooth muscle cells.

The finding of inflammation in the airways of asthmatics even at a clinically early stige of the disease has led to the hypothesis that the underlying inflammation is a major contributor to the physiological changes in asthma (7). This hypothesis has been strengthened by the finding that inflammatory cells will release specific mediators during the asthmatic response that have the capacity to cause somc of the histological and physiological changes that are found in asthma (8.9). In addition, Hogg and colleagues (5, I0) have clegantly demonstrated that moderate amounts of atwaly wall thickening, as seen with inflammation, could profoundly affect the airway narrowing caused by smooth muscle shortening. However, it still remains to be demonstrated

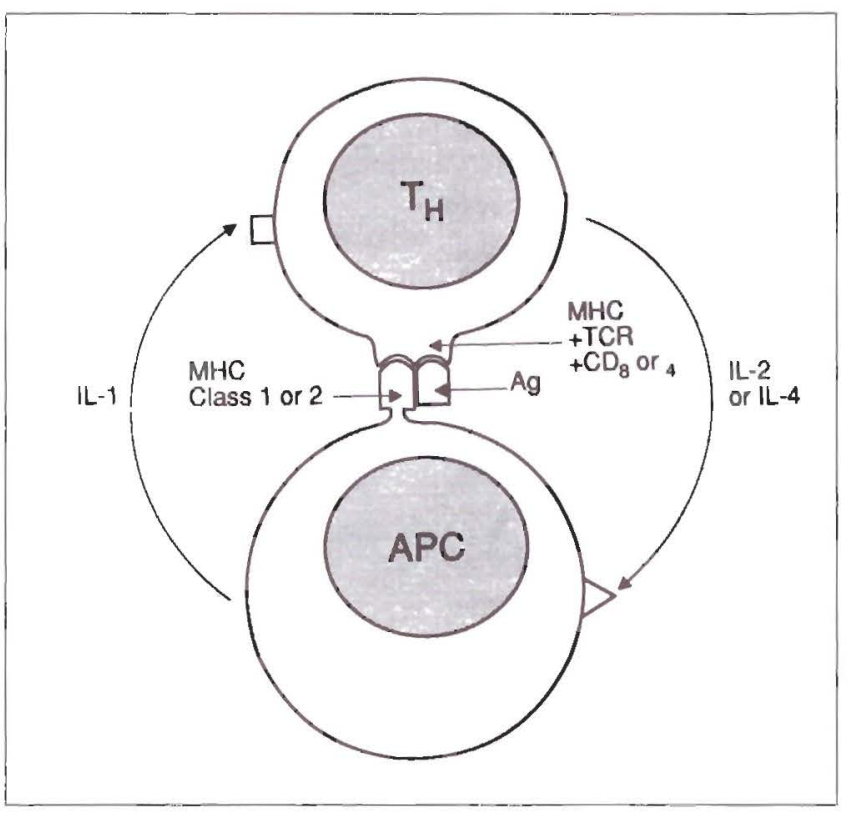

Figure 1) Presentation of antigen to a $T$ lymphocyte (lit): an antigen presenting cell (APC) absorbs and processes the anrigen and presents a peptide to a $T$ lymphocyte in association with its major histocompatibility complex (MHC). The lymphocyte recognizes a specific antigen through its receptor (TCR) in association with $M H C$ and $C D 4$ or 8 , depending on whether the Tlymphocyte is a helper or cytotoxic/suppressor cell, respectively. Certain helper limphorves communicate with APCs by releasing the lymphokines interkikin $(I L)-2$ or -4. Some APC communicate with $T$ lympho(ve's by reasing the cyokins' II.-1

which cell(s) or which mediator(s) are important players in the chronic changes found in the airways of asthmatics.

\section{ASTHMA IN CHILDREN COMPARED WITH ADULTS}

Because of the characteristics of the disease, there are important similarities between the different features of asthma in every age group (11). Symptoms such as shortness of breath, cough, phlegm, wheezing, and the physical signs of tachypnea, tachycardia, wheezing and increased expiratory time are present in infants, children and adults. Laboratory tests show reversible bronchial obstruction and increased airway responsiveness to histamine or methacholinc in every age group. Eosinophilia is found in the bloot of asthmatic and atopic children and ahuts but usually not in the blood of infants (12).

The prevalence of asthma depends on the age and the sex of the group that is studied but usually varies between 5 and $10 \%$ (3). Asthma usually begins in childhood and up to $85 \%$ of individuals experience their first symtoms of asthma before the age of 40 years $(13,14)$. Although a substantial number of children have a remission of asthma at puberty, approximately $50 \%$ of children with asthma will still have symptoms in adult life (14). The development of asthma for the first time is rare in the elderly; however the prevalence of asthma in people over 70 is similar to that found in other age groups ( 13$)$. 
LYMPHOKINES AFFECTING THE ACTIVATION AND PROLIFERATION OF INFLAMMATORY CELLS

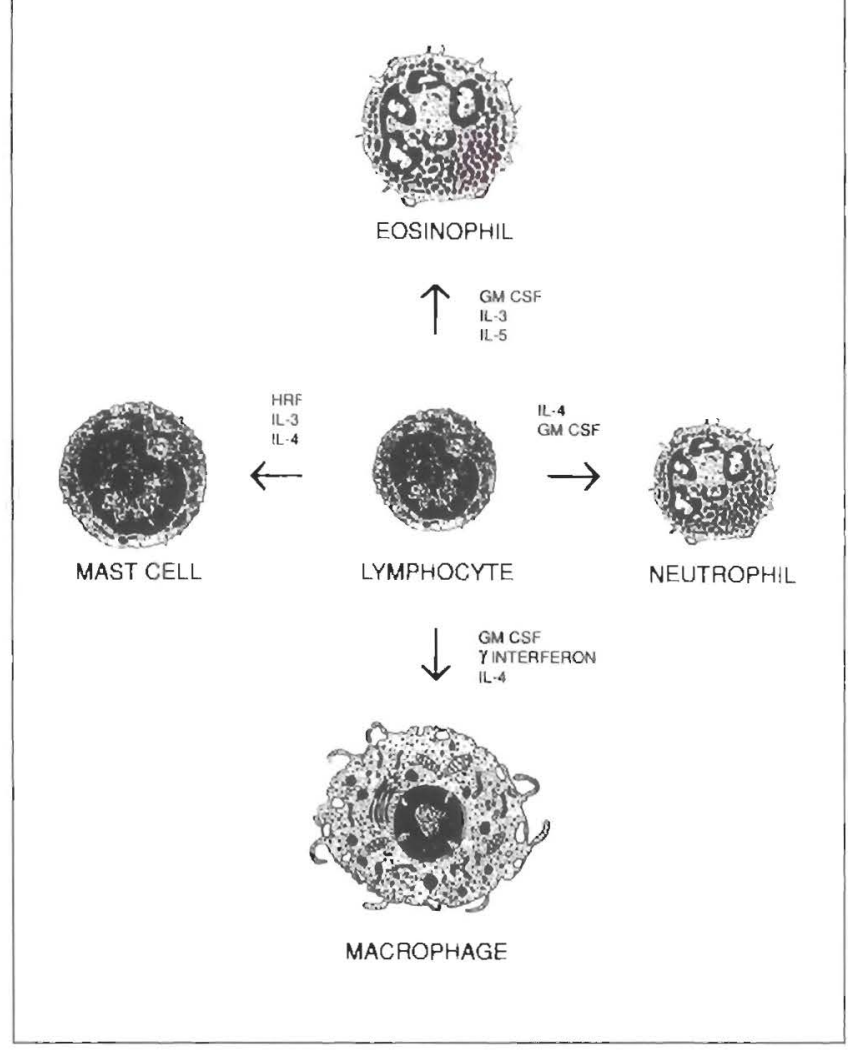

Figure 2) Communication betwe'n 7 / wmphocytes and othe' inflammatory cells: T lymphocytes reledse mediators or 'lymphokines'. which can activate andlor indue' the proliferation of other inflammatory cells. GM-CSF Gromulerye and menerophuge colony stimulating factor; HRF Histanime reletsing factor; It. Interteuhin

There is a difference in the factors that provoke asthma in different age groups. Infants and young children are more susceptible to viral infections $(11,12)$. Children. adolescents and young adults are more susceptible to allergens $(4,11)$ and older adults can be affected by all the different provoking factors, although the prevalence of allergic factors in asthma decreases with age (13).

The histopathology of the airways of patients who die from asthma is the same irrespective of age. Consistent changes are epithelial cell desquamattion, thickening of the basement membrane, an inllammatory cell infiltration and hypertrophy or hyperplasia of snooth muscle $(1,6)$. An association between asthma and atopy exists mostly in children and young adults and a direct correlation has been reported between serum immunoglobulin $(\mathrm{Ig}) \mathrm{E}$ levels and the presence of asthma in children and audults $(13,15,16)$.

The differences in serum IgE levels are also alccompanied by cellular activation, as shown by an increased expression of the interleukin (IL)-2 receptor, human leukocyte antigen (HLA) DR, and virus-like antigen-I on the surface of cells obtained from blood or lung lavage of asthmatic patients (17-19). It is not known whether cellular activation is present
TABLE 1

Lymphokines produced by helper T lymphocyte clones in mice

\begin{tabular}{lcc}
\hline & TH1 & TH2 \\
\hline Interferon gamma & + & - \\
Interleukin-2 & + & - \\
Lymphotoxin & + & - \\
GM-CSF & + & + \\
Tumour necrosis factor & + & + \\
Interleukin-3 & + & + \\
interleukin-4 & - & + \\
Interleukin-5 & - & + \\
Interleukin-6 & - & + \\
Interleukin-10 & - & + \\
interleukin-13 & - & + \\
\hline
\end{tabular}

GM-CSF Granulocyte and macrophage colony stimulating factor

in asthmatic infants. In a recent study we found an increased expression of the IL-2 receptor and CD23 (low affinity IgE receptor) on the mononuclear cells obtained from the blood of infants admitted to the hospital for acute bronchiolitis, a disease characterized by shortness of breath, hyperinflation with or without wheezing and fever that is followed by persistent whee $/$ ing in up to $50 \%$ of the affected infants ( I2). The level of expression of these two receptors, although increased, seems to be less than that found on blood mononuclear cells obtained from older asthmatics during an exacerbation $(20,21)$.

The important association among serum IgE levels, cellular activation and asthma suggests that the mechanisms involved in cellular activation and IgE production may modulate the increased airway responsiveness found in asthma. A better understanding of the abnormalities of the immune response described in this disease could thus lead to a better treatment of asthmil.

\section{EFFECT OF ANTIGENIC STIMULATION ON THE IMMUNE RESPONSE}

When in antigen comes into contact with the immune system it is generally absorbed or phagocytosed by an antigenpresenting cell, which could be a macrophage, a B lymphocytc or a dendritic cell. The antigen-presenting cell modifies the intigen and presents a peptide obtained from it to a $\mathrm{T}$ lymphocyte that has differentiated to recognize specifically the peptide sequence (cpitope) that is presented (Figure 1).

Antigen presentation involves the major histocompatibility complex (HLA) and adhesion molecules, and is generally followed by cellular activation, expression of adhesion molecules that are specific for activation and the progressive release of different messengers called cytokines. These changes occur whether the antigen is an allergen or a virus and will usually be followed by cellular proliferation. The lymphokines (cytokiness produced by lymphocytes) that are released could lead to activation or proliferation of lymphocytes, mast cells, eosinophils, macrophages and neutrophils (Figure 2). 
Several types of helper lymphocytes can be described on the basis of the mRNA for the lymphokines produced. In mice, two major types of cellular clones have been described (22). The TH1 type of helper T lymphocyte plays a role in delayed type hypersensitivity reactions, and the TH2 type of helper $\mathrm{T}$ lymphocyte affects immediate hypersensitivity reactions (Table 1). This separation is important in understanding atopy and asthma for the following reasons: IL-5 is onc of the most important factors involved in activation and proliferation of eosinophils (23): and IL-4 is an important modulator of increased IgE production, whereas interferon gamma blocks the production of $\mathrm{IgE}$ and fivours the production of specilic $\operatorname{IgG}(24,25)$.

It has recently been shown in adult asthmatics that helper T lymphocytes in the blood and lungs express and produce more of the TH2 profile of lymphokines or, at least under certatin circumstances, do not express more interferon gamma than control patients (26-28). These observations have also been found in the blood of children with asthma (personal communication). In studies performed at Hôpital Ste-Justine in Montreal we have found a significant corrclation between the serum level of IL-4 and the number of days of wheezing in infants, between one and four months after a first bronchiolitis (29). Since IL-4 positively affects IgE production, this observation could explain the relationship between the appearance of $\operatorname{IgE}$ in the lungs of infants after bronchiolitis and the development of asthma after bronchiolitis (30).

\section{ROLE OF CELLULAR ACTIVATION AND CYTOKINES IN AIRWAY HYPERRESPONSIVENESS}

Our studies have recently focused on the lymphocyte and its lymphokines. We have studied the effects of IL-2 (T cell growth factor), a lymphokine produced by $\mathrm{T}$ lymphocytes after antigen is presented. Systemic administration of IL-2 to rats can increase the cholinergic responsiveness of the airways and airway responsiveness to ovalbumin in rats that have been previously sensitiod $(31-33)$. Administration of

\section{REFERENCES}

I. Barnes PJ. A new approach to the treatment of asthma. N Engl J Med 1989;321:1517-27.

2. O'Byrne PM, Dolovich J, Hargreave FE. Late asthmatic responses. Am Rev Respir Dis 1987;136:740-51.

3. Weiss KB, Wagener DK. Changing patterns of asthmil mortality. Identifying target populations at high risk. JAMA 1990;264:1683-7.

4. Gergen PJ, Weiss KB. Changing patterns of asthma hospitalization among children: 1979 to 1987. JAMA 1990;264: I688-92.

5. James AL, Paré PD, Hogg JC. The mechanics of airway narrowing in asthma. Am Rev Respir Dis 1989;139:242-6.

6. Dunnil MS. The pathology of asthma, with special reference to changes in the bronchial mucosa. J Clin Pathol 1960;13:27-33.

7. Laitinen LA, Laitinen A, Haahtela T. Airway mucosal inflammation even in patients with newly diagnosed asthmit. Am Rev Respir Dis 1993;147:697-704.

8. Gerblich AA, Salik H, Schuyler MR. Dynamic T-cell changes in peripheral blood and hronchoalveolar lavage after antigen bronchoprosocation in asthmatics. Am Rev Respir Dis
IL-2 also increases cellular inflammation around the bronchovascular tree in rats.

When lymphocytes are obtained from the blood of asthmatic subjects and stimulated with $\mathrm{IL}-2$, their supernatant causes increased survival of eosinophils and increased proliferation of eosinophil progenitors compared with supernatant obtained from control lymphocytes stimulated with IL-2 (21). Since IL-2 causes eosinophilia in humans by increasing the production of IL-5 (34), and since IL-5 is released in the lungs of asthmatics after antigen challenge (23), it thus seems that cellular immunity and lymphokine production can play a rolc in atrway inflammation and hyperresponsiveness in asthmatics.

\section{CONCLUSION}

Exposure of the immune system to a provoking fitctor such as a virus, an allergen or even a "self' antigen will cause inflammation of the airways in the individual with a genetic predisposition. Inflammation will persist in every age group either by continued exposure to triggers or by absence of suppression of the immune reaction and can cause the histological and physiological changes found in asthma.

The treatment of asthma should focus on prevention of exposure to triggering factors, inhibition of activation of inflammatory cells or of the release of specific mediators. In the future, certain therapies will focus on modulation of inflammation by cytokines or by their specific inhibitors. Since important similarities exist among the clinical, physiological and cellular changes found in every age group with asthma, prevention should be implemented at the youngest age possible $(35,36)$. However, we have not been able to identify the specific characteristics of the population at risk for asthma $(37,38)$. Until research on this topic has enlightened us further, avoidance of exposure to allergens, especially in infants with neonatal respiratory complications or a family history of atopy, should be implemented. The substances that should be avoided are allergens such as the house dust mite, cockroaches and cigarette smoke.

1991;143:533-7.

9. Cookson WOCM, Craddock CF, Benson MK, Durham SR. Falls in peripheral eosinophil counts parallel the late asthmatic response. Am Rev Respir Dis 1989;139:456-62.

10. Wiggs BR, Bosken C, Paré PD, James A, Jogg JC. A model of airway narrowing in asthma and in chronic obstructive pulmonary disease. Am Rev Respir Dis 1992;145:1251-8.

I I. Larsen GL. Asthma in children. N Engl J Med 1992;326:1540-5.

12. Wohl MEB, Chernick V. State of the art. Bronchiolitis. Am Rev Respir Dis 1978;1 18:759-81.

13. Braman SS, Kaemmerlen JT, Davis SM. Asthma in the elderly. A comparison between patients with recently acquired and long-standing disease. Am Rev Respir Dis 1991;143:336-40

14. Gerritsen J, Koeter GH, Postma DS, Schouten JP, Knol K. Prognosis of asthma from childhood to adulthood. Am Rev Respir Dis 1989;140:1325-30.

15. Sears MR, Burrows B, Flannery EM, Herbison GP, Hewitt CJ, Holdaway MD. Relation between airway responsiveness and serum IgE in children with asthma and in apparently normal children. N Engl J Med 1991;325:1067-71. 
16. Burrows B, Martinc FI). Halonen M, Barbee RA, Cline MG. Association of asthma with serum IgE levels and skin-test reactivity to allergens. $N$ Engl J Med 1989;320:271-7.

17. Corrigan CJ, Haczku A, Gemou-Engesaeth V, et al. CD4 T-Lymphocyte activation in asthma is accompanied by increased serum concentrations of interleukin-5. Effect of glucocorticoid therapy. Am Rev Respir Dis 1993;147:540-7.

18. Ferguson AC, Wong FWM. Bronchial hyperresponsiveness in asthmatic children. Correlation with macrophages and eosinophils in broncholavage fluid. Chest 1989;96:988-91.

19. Walker C, Bode E, Boer L, Hansel TT, Blaser K, Virchow JC $\mathrm{Jt}$. Allergic and nonallergic asthmatics have distinct patterns of $T$-cell activation and cytokine production in peripheral blood and hronchosilveolar lavage. Am Rev Respir Dis 1992;146:109-15.

20. Yang JP, Spier S, Turgeon J, Drblik SP, Pedneault L. Renzi PM. Lymphocyte profile and cytokine production in the bloud of infants with acute bronchiolitis. Am Rev Respir Dis 1993; 147:A132. (Abst)

2I. Yang JP, Renzi PM. Interlcukin-2 and lymphocyte-induced eosinophil proliferation and survival in asthmatic patients. J Allergy Clin Immunol 1993;91:792-801.

22. Mosmann TR, Cherwinski H, Bond MW, Gicldin MA Coffman RL. Two types of murine helper T cell clones. 1 . Definition according to profiles of lymphokine activitics and secreted proteins. J Immunol 1980; 136:2348-57.

23. Ohnishi T, Kita H, Weiler D, et al. IL 5 is the predominint eosinophil-active cytokine in the antigen-induced pulmonary late-phase reaction. Am Rev Respir Dis 1993;147:901-7.

24. de Vries JE, Gauchat JF, Aversa GG, Punnonen J, Gascan H, Yssel H. Regulation of IgE synthesis by cytokines. Curr Opin Immunol 1991;3:851-8.

25. Finkelman FD, Katona IM, Urban JF Jr, et al. IL-4 is required to generate and sustain in vivo IgF. responses. J Immunol $1988 ; 141: 2335-41$

2(). Robinson DS, Hamid Q. Ying S, cl al. Predominant TH2-Like bronchoalveolar T-lymphocyte population in alopic asthma. N Engl J Med 1992;326:298-304.

27. Krishnaswamy G, Liu MC, Su SN, et al. Analysis of cytokine transcripts in the bronchoalveolar cells of patients with asthma.
Am J Respir Cell Mol Biol 1993;9:279-86.

28. Corrigan CJ, Kay AB. CD4 T-lymphocyte activation in acute severe asthma. Am Rev Respir Dis 1990;141:970-7.

29. Spier S, Yang JP, Drblik SP, Turgeon S, Marcotte JE, Renzi PM. Infantile wheezing (W): correlates with T-Lymphocytc helper 2 (TH2) cell activity but not bronchial reactivity ( $\mathrm{Br}$ ). Am Rev Respir Dis 1993; 147:A132. (Abst)

30. Welliver RC, Kaul TN, Ogra PL. The appearance of cell bound $\mathrm{IgE}$ in respiratory-tract epithelium after respiratory-syncytial-virus infection. N Engl J Med 1980:303:1 198-202.

31. Renzi PM, Du T, Sapienza S, Wang NS, Martin JC, Acutc effects of interleukin-2 on lung mechanics and airway responsiveness in rats. Am Rev Respir Dis 1991:143:380-5.

32. Renzi PM, Sapienza S, Waserman S, Du T, Olivenstein R, Wang NS, Martin JG. Effect of interleukin-2 on the airway response to antigen in the Rat. Am Rev Respir Dis 1992; 146: [63-9.

33. Renzi PM, Spienza S, Du T, Wang NS, Martiu JG. Lymphokine-induced airway hyperresponsiveness in the rat. Am Rev Respir Dis 1991; 143:375-9.

34. Enokihara H, Furusawa S, Nakakubo H, et al. T cells from eosinophilic patients produce interleukin -5 with interleukin-? stimulation. Blood 1989:73:1809-13.

35. Arshad SH, Matthews S, Gant C, Hide DW. Effect of allergen avoidance on development of allergic disorders in infancy. Lancet 1992:339:1493-7.

36. Sporik R, Holgate ST, Platts-Mills TAE, CogsweIl JJ. Exposure to house-dust mite allergen (Der pI) and the development of asthma in childhood. N Engl J Med 1990;323:502-7.

37. Martinez FD, Morgan WJ, Wright AL, Holberg CJ, Taussig LM, and the Group Health Medical Associates Personnel. Diminished lung function as a predisposing factor for wheezing respiratory illness in infants. $\mathrm{N}$ Engl J Med 1988:319:1112-7.

38. Young S, Le Souef PN, Geelhoed GC, Stick SM, Turner K.J Landau LI. The influence of a family history of asthma and parental smoking on airway responsiveness in early infancy. N Engl J Med 1991;324: I 168-73. 


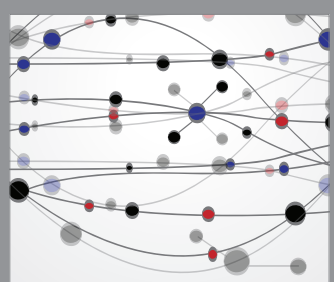

The Scientific World Journal
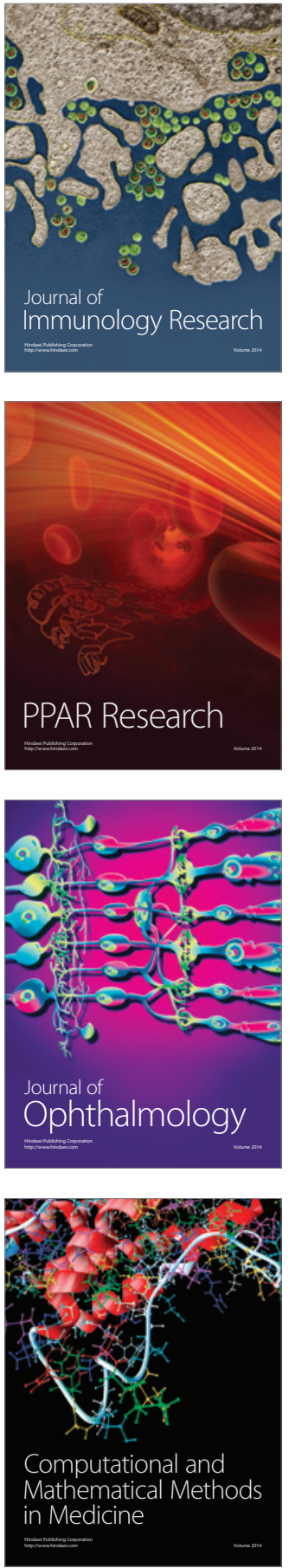

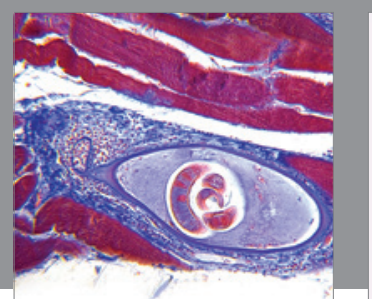

Gastroenterology Research and Practice

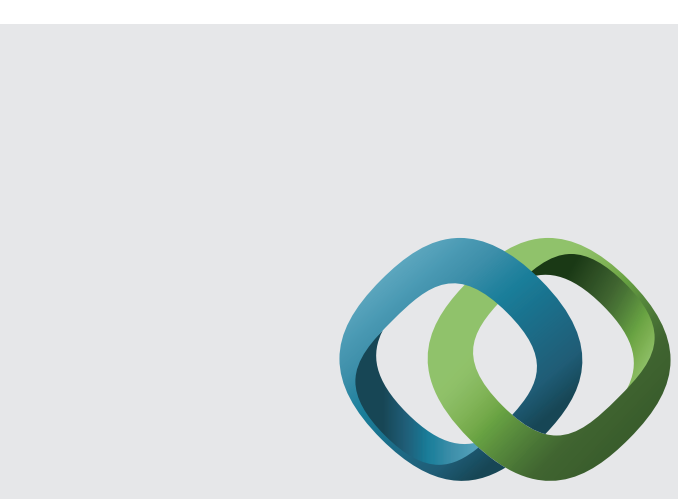

\section{Hindawi}

Submit your manuscripts at

http://www.hindawi.com
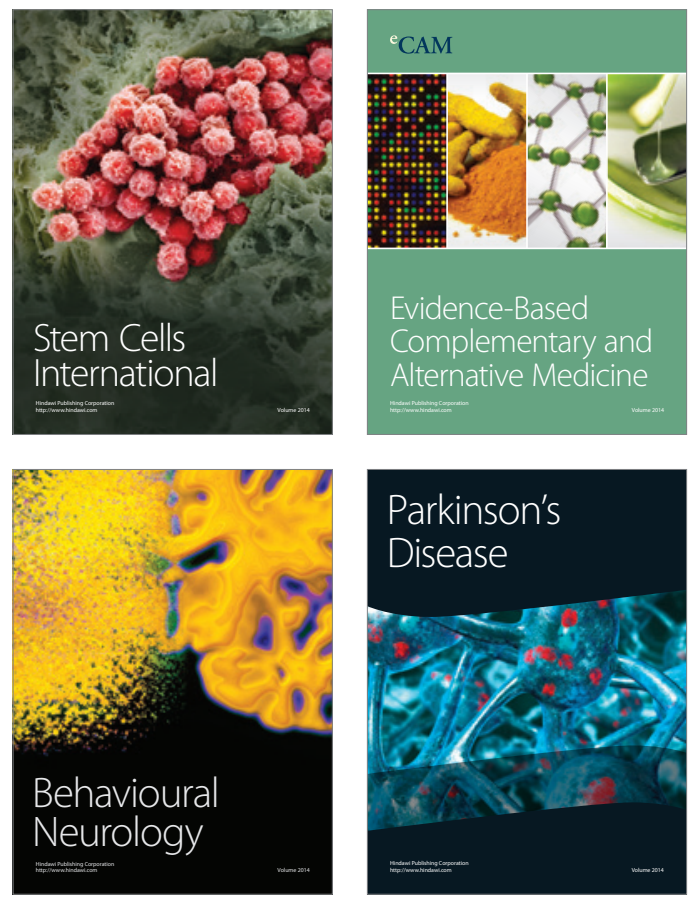
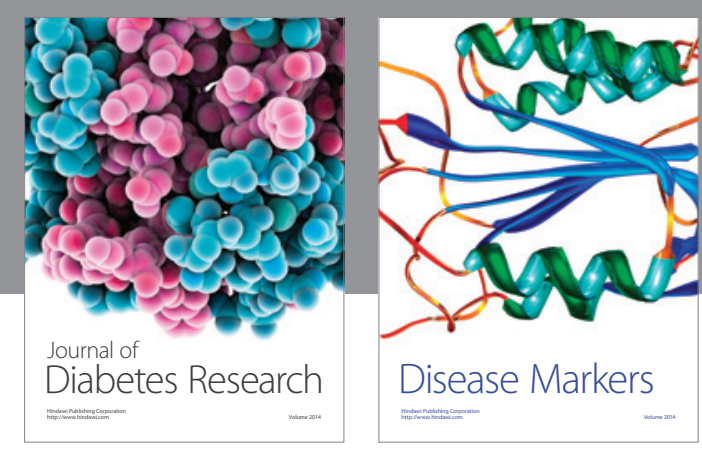

Disease Markers
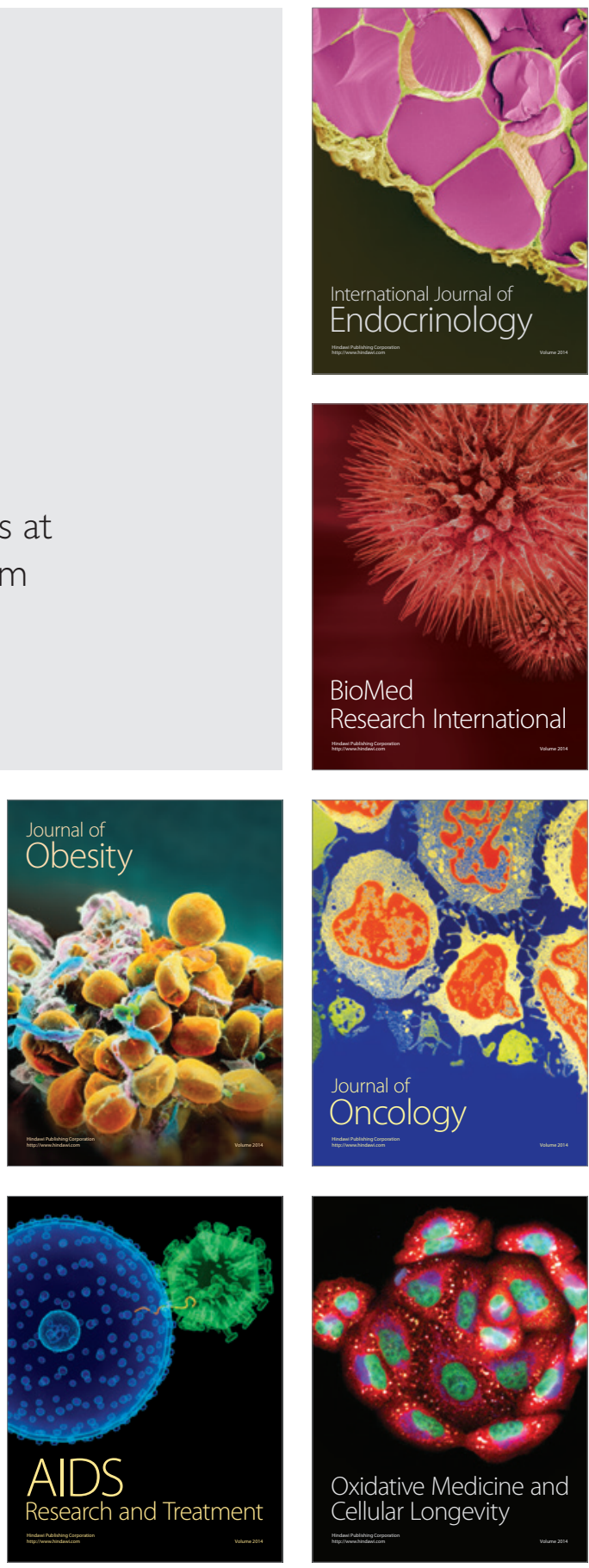